\title{
Impact of divorce on the quality of life in school-age children
}

\author{
Alfredo Eymann, ${ }^{1}$ Julio Busaniche, ${ }^{1}$ Julián Llera, $^{2}$ \\ Carmen De Cunto, ${ }^{3}$ Carlos Wahren ${ }^{4}$
}

\begin{abstract}
Objective: To assess psychosocial quality of life in school-age children of divorced parents.

Methods: A cross-sectional survey was conducted at the pediatric outpatient clinic of a community hospital. Children 5 to 12 years old from married families and divorced families were included. Child quality of life was assessed through maternal reports using a Child Health Questionnaire - Parent Form 50. A multiple linear regression model was constructed including clinically relevant variables significant on univariate analysis (beta coefficient and $95 \% \mathrm{CI}$ ).

Results: Three hundred and thirty families were invited to participate and 313 completed the questionnaire. Univariate analysis showed that quality of life was significantly associated with parental separation, child sex, time spent with the father, standard of living and maternal education. In a multiple linear regression model, quality of life scores decreased in boys $-4.5(-6.8$ to -2.3$)$ and increased for time spent with the father $0.09(0.01$ to 0.2$)$. In divorced families, multiple linear regression showed that quality of life scores increased when parents had separated by mutual agreement 6.1 (2.7 to 9.4), when the mother had university level education 5.9 (1.7 to 10.1 ) and for each year elapsed since separation $0.6(0.2$ to 1.1$)$, whereas scores decreased in boys $-5.4(-9.5$ to -1.3$)$ and for each one-year increment of maternal age -0.4 ( -0.7 to -0.05$)$.

Conclusion: Children's psychosocial quality of life was affected by divorce. The Child Health Questionnaire can
\end{abstract} be useful to detect a decline in the psychosocial quality of life.

J Pediatr (Rio J). 2009;85(6):547-552: Argentina, child, health status, health-related quality of life, family relations, Child Health Questionnaire.

\section{Introduction}

Divorce is becoming increasingly prevalent in our society, significantly affecting all parties involved, particularly children. ${ }^{1}$ Studies in the USA and in Europe have estimated that 30 to $50 \%$ of children will suffer consequences from a divorce ${ }^{1-3}$; similar rates have been reported in Argentina. ${ }^{4}$

Parental separation is often the first major change in a child's life. This distressing event drastically alters the family's future, bringing a sense of loss due to disruption in normal routines as well as absence of daily contact with both parents. ${ }^{5-7}$

Developmental and behavioral disorders, both prior to divorce and in particular during the first years following the event, have been reported. ${ }^{8-10}$ Many studies have shown that parental divorce affects a child's physical and psychosocial health, although results differ according

1. MD. General Pediatrics, Professor of Pediatrics, Department of Pediatrics, Hospital Italiano de Buenos Aires (HIBA), Buenos Aires, BA, Argentina

2. MD. Head, General Pediatrics, Professor of Pediatrics, Department of Pediatrics, HIBA, Buenos Aires, BA, Argentina.

3. MD. Head, Pediatric Rheumatology Section, Department of Pediatrics, HIBA, Buenos Aires, BA, Argentina.

4. MD. Chairman, Department of Pediatrics, Professor of Pediatrics, HIBA, Buenos Aires, BA, Argentina.

This study was conducted at Servicio de Clínica Pediátrica, Department of Pediatrics, Hospital Italiano de Buenos Aires (HIBA), Buenos Aires, BA, Argentina. No conflicts of interest declared concerning the publication of this article.

Suggested citation: Eymann A, Busaniche J, Llera J, De Cunto C, Wahren C. Impact of divorce on the quality of life in school-age children. J Pediatr (Rio J). 2009;85(6):547-552.

Manuscript submitted Jul 21 2009, accepted for publication Oct 192009.

doi:10.2223/JPED.1958 
to study design and the instruments used to measure outcomes. $^{8-16}$ We are aware that psychosocial health is a complex construct, multidimensional in nature but often reduced by researchers to a single structure for operational purposes which are affected by a number of factors such as parental characteristics, style of child rearing, community values, child adaptability, etc.

Generic health-related quality of life questionnaires are valid tools to measure both physical and psychosocial health in children. ${ }^{17,18}$ To our knowledge no studies have been published to date concerning psychosocial quality of life in children of divorced parents.

The aim of this study was to assess psychosocial quality of life in school-age children of divorced parents using a generic quality of life child health questionnaire.

\section{Methods}

A cross-sectional study was conducted at the Hospital Italiano, a private community hospital in Buenos Aires, Argentina. From August through November 2002 mothers of patients 5 to 12 years old attending the pediatric outpatient clinic were invited to participate in the survey.

Non-randomized, consecutive sampling of children of divorced parents was performed prior to consultation, next patient of non-divorced parents matched for age, was selected as control. Mothers of children selected to participate gave informed consent. Single or widowed mothers were excluded from the study as were children who were not accompanied by their mother, as well as children with chronic illnesses or acute conditions severe enough to affect the survey. Children attending clinic with their father were also excluded because this is not the usual practice. If the mother had come with more than one eligible child, the eldest was selected for the study.

We defined divorced family (DF) as parents who choose to keep separate residence regardless of legal marital status and married family (MF) as parents sharing residence with their children regardless of legal marital status.

The generic quality of life Child Health Questionnaire - Parent Form 50 (CHQ-PF 50) designed in 1996 by Landgraf et al. ${ }^{19}$ in its validated Argentine-Spanish version ${ }^{20}$ was used. This is a parent-reported questionnaire assessing a child's physical and psychosocial health. It comprises 50 questions in 14 domains (physical functioning, role social-physical, general health, bodily pain, parental impacttime, parental impact-emotional, role social-emotional, role social-behavioral, self-esteem, mental health, general behavior, family activities, family cohesion, changes in health) and two summary scores (physical health and psychosocial health) ranging from 0 to 100 with higher scores indicating better quality of life.
The following adjustment variables were recorded: health insurance coverage, child gender, siblings, maternal age and educational level, time spent with the father measured in weekly hours while awake, and decline in economic standard of living in the last year as evidenced by change of schools, moving house and/or interrupting previous activities due to loss of income.

To control for known confounders in divorced families four additional questions were developed, namely: time elapsed since separation, new maternal partner, legal separation terms or conditions (litigant or mutual agreement) and type of child custody (held by mother, father or joint custody).

Sample size was calculated in order to detect a clinically relevant five-point difference in the psychosocial summary score, assuming alpha $=0.05$ and $80 \%$ power for a twotailed Student's $t$ test in 150 subjects per group.

Normality was assessed using graphs and the ShapiroWilk test. Continuous variables were compared using Student's $t$ test for normally distributed data and the Wilcoxon test for non-normally distributed data. Categorical variables were assessed using the chi-square test. A multiple linear regression model was constructed including clinically relevant variables significant on univariate analysis. We tested assumptions of multiple regression (independence, normality, multicollinearity, homoscedasticity) and applied robust multiple linear regression models when an assumption was not met.

Statistical analysis was performed using Stata 8.0 software (Stata Corporation, Texas, USA).

The study was approved by the institutional review board.

\section{Results}

A total of 330 mothers were invited to participate in the survey, of whom 17 either declined to answer the questionnaire or did so in an incomplete manner. Three hundred and thirteen surveys were obtained for analysis: 160 from MF and 153 from DF.

Demographic and socioeconomic characteristics are summarized in Table 1 . Time spent with the father was significantly lower (15.1 vs. $42.2 \mathrm{~h} /$ week, $\mathrm{p}=0.0001$ ) and the general standard of living showed a significant difference (37.7 vs. $10 \%, p<0.00001$ ) in DF than in MF.

Mean CHQ-PF 50 domain and summary scores comparing married and divorced families are shown in Table 2. Domain scores of time impact on the family, social emotional functioning and behavior, self-esteem, mental health and behavior were significantly lower in DF. The psychosocial summary score was significantly higher in MF than in DF (52 vs. 46.6, $p<0.00001$ ) whereas no difference was found in the physical summary score between groups (Table 2 ). 
Univariate analysis showed significant difference in psychosocial summary scores for the following variables: parental divorce $(p<0.0001)$, sex $(p<0.0001)$, time spent with the father $(p<0.0001)$, decline in standard of living $(p<0.0001)$ and maternal university education $(p=0.008)$ (Table 3$)$.

In multivariate analysis, psychosocial quality of life scores improved on average 0.1 point [ $95 \%$ confidence interval
( $95 \% \mathrm{CI}) 0.01$ to 0.2 ] for each weekly hour spent with the father and declined on average 4.5 points ( $95 \%$ CI 2.3 to 6.7) in boys, after adjusting for other variables. Despite the fact that in univariate analysis there was a significant association for parental divorce, in multivariate analysis this association was not significant after introducing the variable time spent with the father into the model (Table 3). We reviewed the behavior of this variable in both MF

Table 1 - Sociodemographic characteristics of the families included in the survey

\begin{tabular}{|c|c|c|c|}
\hline Characteristics & $\begin{array}{l}\text { Married family, \% } \\
\quad(n=160)\end{array}$ & $\begin{array}{l}\text { Divorced family, \% } \\
\qquad(n=153)\end{array}$ & $\mathbf{p}$ \\
\hline Marital status & $\begin{array}{c}\text { Married: } 90.6 \\
\text { Common law: } 9.4\end{array}$ & $\begin{array}{l}\text { Divorced: } 43.1 \\
\text { Separated: } 56.9\end{array}$ & \\
\hline Health insurance coverage & 100 & 100 & \\
\hline Age of mother (years)* & $38.1 \pm 7.1$ & $36.7 \pm 5.1$ & $0.1^{+}$ \\
\hline \multicolumn{4}{|l|}{ Maternal education } \\
\hline $\begin{array}{l}\text { Primary } \\
\text { High school } \\
\text { College } \\
\text { University }\end{array}$ & $\begin{array}{c}6.8 \\
36.2 \\
21.2 \\
35.6\end{array}$ & $\begin{array}{c}5.8 \\
47 \\
25.4 \\
21\end{array}$ & $\begin{array}{c}0,7^{\ddagger} \\
0.054^{\ddagger} \\
0.4^{\ddagger} \\
0.006^{\ddagger}\end{array}$ \\
\hline Child gender (male) & 51.2 & 54.9 & $0.5^{\ddagger}$ \\
\hline Age of child (years)* & $8.4 \pm 2$ & $9.3 \pm 2$ & $0.0002^{+}$ \\
\hline Siblings & 73.7 & 68.6 & $0.3^{\ddagger}$ \\
\hline Time spent with father (h/week)* & $42.4 \pm 16.9$ & $15.1 \pm 12.6$ & $0.0001^{\S}$ \\
\hline Decline in standard of living & 10 & 37.2 & $<0.00001^{\ddagger}$ \\
\hline
\end{tabular}

$\mathrm{SD}=$ standard deviation

${ }^{*}$ Mean \pm SD.

† Student's $t$ test.

‡ Chi-square.

$\S$ Wilcoxon test.

Table 2 - Mean CHQ-PF 50 domain and summary scores in married and divorced families

\begin{tabular}{|c|c|c|c|}
\hline Domain & $\begin{array}{l}\text { Married family, } n=160 \\
\quad(\text { mean } \pm \text { SD })\end{array}$ & $\begin{array}{l}\text { Divorced family, } n=153 \\
\quad(\text { mean } \pm \text { SD })\end{array}$ & $\mathbf{p}$ \\
\hline Physical function & $96.4 \pm 9.9$ & $93.1 \pm 12.4$ & 0.01 \\
\hline Role social-physical & $94.2 \pm 15.9$ & $93,1 \pm 15.2$ & 0.55 \\
\hline General health & $75 \pm 12.8$ & $76.1 \pm 13.4$ & 0.45 \\
\hline Bodily pain & $79.8 \pm 21.4$ & $76 \pm 2$ & 0.10 \\
\hline Parental impact-time & $92.7 \pm 13$ & $89.1 \pm 16.3$ & 0.04 \\
\hline Parental impact-emotional & $69 \pm 29.4$ & $64.1 \pm 27.6$ & 0.1 \\
\hline Role emotional-behavioral & $95.4 \pm 13.3$ & $89.1 \pm 16.7$ & 0.0003 \\
\hline Self-esteem & $89.5 \pm 12.5$ & $80.3 \pm 21.2$ & $<0.00001$ \\
\hline Mental health & $74.5 \pm 16.5$ & $69 \pm 19.4$ & 0.008 \\
\hline General behavior & $76 \pm 15.4$ & $68.8 \pm 16.7$ & 0.0001 \\
\hline Family cohesion & $73.6 \pm 17$ & $71.5 \pm 21.7$ & 0.3 \\
\hline Family activities & $85.9 \pm 15.4$ & $84.7 \pm 14.6$ & 0.45 \\
\hline Physical summary score & $52.6 \pm 6.7$ & $52.5 \pm 7.2$ & 0.9 \\
\hline Psychosocial summary score & $52 \pm 7.4$ & $46.6 \pm 11.4$ & $<0.00001$ \\
\hline
\end{tabular}

CHQ-PF 50 = Child Health Questionnaire PF 50; SD = standard deviation. 
and DF and found significant association in MF but not in DF (beta coefficient $0.26, p=0.002$ vs. beta coefficient $0.13, p=0.1$ ); thus time spent with father acted as an effect modifier.

On analyzing the DF group, $88 \%$ had separated more than 2 years ago, in $92.2 \%$ the mother had legal custody, separation had been by mutual agreement in $68.8 \%$ and $23.6 \%$ of mothers were living with a new partner.

In the DF group, univariate analysis showed significant difference in psychosocial quality of life scores for the following variables: separation by mutual agreement $(\mathrm{p}=$ $0.003)$, child sex $(p=0.001)$, maternal university education $(p=0.002)$, age of mother $(p=0.02)$, and length of time since separation $(p=0.03)$. In multivariate analysis psychosocial quality of life scores increased on average 6 points ( $95 \%$ CI 2.7 to 9.4 ) for separation by mutual agreement , 5.9 points ( $95 \%$ CI 1.6 to 10.1 ) for maternal university education, 0.6 points ( $95 \%$ CI 0.1 to 1.1 ) for each year elapsed since separation, whereas scores decreased 5.4 points ( $95 \% \mathrm{CI}-9.5$ to -1.3$)$ in boys and 0.4 points ( $95 \% \mathrm{CI}$
-0.7 to -0.05$)$ for each one-year increment of maternal age, after adjusting for the remaining variables (Table 4).

\section{Discussion}

The results of this study show that divorce affects children's quality of life. CHQ-PF 50 scores were lower in children of DF than in those of MF for various domains, namely time impact on family, social-emotional functioning and behavior, self-esteem, mental health, behavior and finally the psychosocial summary score integrating all these variables. These results agree with those reported in a quality of life survey conducted in a group of Austrian elementary school children. ${ }^{21}$

To our knowledge this is the first study using a quality of life questionnaire to assess the impact of parental divorce on children.

As shown in the results, boys had poorer psychosocial quality of life than girls, a finding explained perhaps by the effects of less frequent father-child contact on gender-

Table 3 - Variables associated with psychosocial quality of life in univariate and multivariate analyses*

\begin{tabular}{|c|c|c|c|c|}
\hline \multirow[b]{2}{*}{ Variables } & \multicolumn{2}{|c|}{ Univariate analysis } & \multicolumn{2}{|c|}{ Regression with robust SE } \\
\hline & OR $(95 \% \mathrm{CI})$ & $\mathbf{p}$ & Beta coefficient $(95 \% \mathrm{CI})$ & $\mathbf{p}$ \\
\hline Parental divorce & $-5.37(-7.67$ to 3.07$)$ & $<0.0001$ & $-2(-5$ to 0.8$)$ & 0.2 \\
\hline Child gender (male) & $-5.25(-7.56$ to 2.94$)$ & $<0.0001$ & $-4.5(-6.8$ to -2.3$)$ & $<0.0001$ \\
\hline $\begin{array}{l}\text { Time spent with father } \\
\text { (hours/week while awake) }\end{array}$ & $0.15(0.098$ to 0.21$)$ & $<0.0001$ & $0.09(0.01$ to 0.2$)$ & 0.02 \\
\hline Decline in standard of living & $-5.03(-7.70$ to 2.37$)$ & $<0.0001$ & $-2.2(-5$ to 0.5$)$ & 0.1 \\
\hline Maternal university studies & $3.2(0.84$ to 5.56$)$ & 0.008 & $1.5(-0.7$ to 3.7$)$ & 0.2 \\
\hline
\end{tabular}

$95 \% \mathrm{Cl}=95 \%$ confidence interval; $\mathrm{OR}=$ odds ratio; $\mathrm{SE}=$ standard error.

* Number of observations $=313$.

Table 4 - Variables associated with psychosocial quality of life in univariate and multivariate analyses in divorced families*

\begin{tabular}{|c|c|c|c|c|}
\hline \multirow[b]{2}{*}{ Variables } & \multicolumn{2}{|c|}{ Univariate analysis } & \multicolumn{2}{|c|}{ Regression with robust SE } \\
\hline & Odds ratio $(95 \% \mathrm{CI})$ & $\mathbf{p}$ & Beta coefficient $(95 \% \mathrm{CI})$ & $\mathbf{p}$ \\
\hline Child gender (male) & $-6.3(-10$ to -2.6$)$ & 0.0009 & $-5.4(-9.5$ to -1.3$)$ & 0.01 \\
\hline Maternal university studies & $5.9(2.2$ to 9.6$)$ & 0.001 & $5.9(1.7$ to 10.1$)$ & 0.006 \\
\hline Separation by mutual agreement & $6.1(2.1$ to 10$)$ & 0.002 & $6.1(2.7$ to 9.4$)$ & $<0.0001$ \\
\hline Age of mother & $-0.4(-0.8$ to -0.05$)$ & 0.02 & $-0.4(-0.7$ to -0.05$)$ & 0.02 \\
\hline Time elapsed since separation & $0.8(0.08$ to 1.6$)$ & 0.03 & $0.6(0.2$ to 1.1$)$ & 0.008 \\
\hline
\end{tabular}

$95 \% \mathrm{Cl}=95 \%$ confidence interval; $\mathrm{SE}=$ standard error.

* Number of observations $=153$. 
specific identity traits. Other authors have also reported a greater impact of parental separation on boys, particularly as regards overall behavior, developmental skills and academic achievements. ${ }^{13-15,16,22}$

It is well known that separated mothers, who in general have legal child custody, usually suffer a greater fall in their standard of living; the reports by Felder-Puig et al., ${ }^{21}$ Norton \& Glick, ${ }^{23}$ and Duncan et al. ${ }^{24}$ have clearly described the unfavorable economic consequences of divorce on child well-being. Results of our study in particular should be interpreted in the light of the political-economic crisis prevailing in Argentina at the time of the survey.

Substantial controversy exists concerning how maternal remarriage affects children who must readapt to new family norms and dynamics. However, since parental separation often involves a fall in family income, a new partner could in fact provide additional financial support. Moreover, the new couple may develop an improved marital relationship, thus reducing the distressing emotional burden on children and making the stepfather a positive role model. In this study, maternal remarriage did not appear to impact quality of life scores. Indeed, many studies concluded that children in married families and those in stepfather families fare equally well.16,25,26 In contrast, other investigators suggest that remarriage is a risk factor for child behavior disorders. ${ }^{27}$

In this study, the father's presence had a positive impact on child quality of life in MF, but not in DF. This result should be interpreted with caution and further qualitative studies will be needed to better establish its significance.

The variable time spent with the father was different for both groups: 42.4 vs. $15.1 \mathrm{~h} /$ week in MF and DF respectively. This finding is in agreement with legal child custody status of the sample, $92 \%$ corresponding to the mother and only $8 \%$ to joint custody. No father had sole custody of his child. This distribution coincides with local cultural and legal practices in which mothers are in charge of bringing up the children.

Healey et al. reported that following divorce $50 \%$ of children had no further contact with their father and only a few had stayed the night at their father's house in the past month. ${ }^{28}$ From another standpoint, Martin-Lebrun et al. suggested improved results for the Coopersmith test when children saw their father regularly. ${ }^{22}$

Although the presence of a sibling has been reported as a protective factor, this effect was not observed in our study. ${ }^{29}$ The reason for this may have been the fact that only the eldest child was included, and that he or she tends to take on compensatory roles in family dynamics. Child-age did not impact quality of life scores in this study either.

Separation by mutual agreement, maternal university education or higher maternal education level and longer length of time elapsed since separation increased psychosocial quality of life scores, whereas scores decreased in boys and for each one-year increment of maternal age.

The percentage of parents who did not divorce by mutual agreement or consent is similar to other studies which describe repeated hostile confrontations over child custody or financial issues during a period lasting at least 2 years after the divorce. 30

Higher maternal educational level improves psychosocial quality of life, which may be explained as a consequence of the skills developed through education years, allowing better control of the marital crisis and greater agreement on confrontation issues.

Improvement in quality of life as more time elapses after the divorce may be interpreted as a process of accepting the family modification.

Divorce of parents is probably one of the major events affecting a child's life, causing disruption of the family as a role model and of future life in common. Dealing with the crisis in a constructive manner, however, may help foster the child's psychological development. This will depend mostly on the parents, their conflict-solving abilities, management of anger and loss as well as their awareness of the child's feelings in order to be more understanding and supportive.

This study presents certain limitations. First, the instrument used to measure quality of life outcome did not include self-reporting from the children involved or information pertaining to personal parental view point. Second, a five-point difference in psychosocial quality of life score may represent a limiting factor in distinguishing individual patients. Third, the sample was obtained by a convenience strategy which could imply a potential bias. Finally, some issues may be interpreted more efficiently using qualitative studies.

Notwithstanding, we believe this study provides original and valuable information to better understand and support families suffering the psychosocial consequences of divorce.

In conclusion, children's psychosocial quality of life was affected by divorce.

Psychosocial quality of life improved when parents had divorced by mutual agreement, the mother had a university education, when more time had elapsed since separation and was poorer in boys and in children of older mothers.

This study shows that the CHQ-PF 50 can be a useful and sensitive instrument to detect a decline in the psychosocial quality of life in school-age children of divorced parents.

\section{Acknowledgements}

We thank the Clinical Epidemiology Department for its help in the statistical analysis of the data and Dr. Gustavo Izbizky for his critical reading of the manuscript. 


\section{Referencess}

1. Hernandez DJ. Children's changing access to resources: A historical perspective. Soc Policy Rep. 1994;8:1-21.

2. Robinson M. Family transformation through divorce and remarriage: a systemic approach. London: Routledge; 1991.

3. Shamsie J. Family breakdown and its effects on emotional disorders in children. Can J Psychiatry. 1985;30:281-7.

4. Gobierno de la Ciudad, Registro civil [website]. Argentina, Buenos Aires. http://www.buenosaires.gov.ar/registrocivil/?menu_id=10. Access: $18 / 12 / 2008$.

5. Cohen GJ; American Academy of Pediatrics; Committee on Psychosocial Aspects of Child and Family Health. Helping children and families deal with divorce and separation. Pediatrics. 2002;110:1019-23.

6. Green M. The physician's role in family adaptation to important life events. Death, separation and divorce, birth of an infant with a handicap, and critical illness in a child. Indiana Med. 1987; 80:623-32

7. Emery RE, Coiro MJ. Divorce: consequences for children. Pediatr Rev. 1995;16:306-10.

8. Block JH, Block J, Gjerde PF. The personality of children prior to divorce: a prospective study. Child Dev. 1986;57:827-40.

9. Amato PR, Booth A. A prospective study of divorce and parentchild relationships. J Marriage Fam. 1996;58:356-65.

10. Cherlin AJ, Furstenberg FF Jr, Chase-Landsdale L, Kiernan KE, Robins PK, Morrison DR, et al. Longitudinal studies of effects of divorce on children in Great Britain and the United States. Science. $1991 ; 252: 1386-9$.

11. Amato PR, Keith B. Parental divorce and the well-being of children: a meta-analysis. Psychol Bull. 1991;110:26-46.

12. Block J, Block JH, Gjerde PF. Parental functioning and the home environment in families of divorce: prospective and concurrent analyses. J Am Acad Child Adolesc Psychiatry. $1988 ; 27: 207-13$

13. Fergusson DM, Lynskey MT, Horwood LJ. The effects or parental separation, the timing of separation and gender on children's performance on cognitive test. J Child Psychol Psychiatry. 1994;35:1077-92.

14. Bolgar R, Zweig-Frank $H$, Paris J. Childhood antecedents of interpersonal problems in young adult children of divorce. J Am Acad Child Adolesc Psychiatry. 1995;34:143-50.

15. Wallerstein JS. The long-term effects of divorce on children: a review. J Am Acad Child Adolesc Psychiatry. 1991;30:349-60.

16. Pagani L, Boulerice B, Tremblay RE, Vitaro F. Behavioural development in children of divorce and remarriage. J Child Psychol Psychiatry. 1997;38:769-81.

17. Wallander JL, Schmitt M, Koot HM. Quality of life measurement in children and adolescents: issues, instruments, and applications. J Clin Psychol. 2001;57:571-85.
18. Davis E, Waters E, Mackinnon A, Reddihough D, Graham HK, Mehmet-Radji $\mathrm{O}$, et al. Paediatric quality of life instruments: a review of the impact of the conceptual framework on outcomes. Dev Med Child Neurol. 2006;48:311-8.

19. Landgraf JM, Abetz L, Ware JE. The child health questionnaire: a user's manual. Boston: The Health Institute, New England Medical Center; 1996.

20. Moroldo MB, Ruperto N, Espada G, Russo R, Liberatore D, Cuttica R, et al. The Argentinian version of the Childhood Health Assessment Questionnaire (CHAQ) and the Child Health Questionnaire (CHQ). Clin Exp Rheumatol. 2001;19:S10-4

21. Felder-Puig R, Baumgartner M, Topf R, Gadner H, Formann AK. Health-related quality of life in Austrian elementary school children. Med Care. 2008;46:432-9.

22. Martin-Lebrun E, Poussin G, Barumandzadeh T, Bost M. Psychological effects of parental separation on children. Arch Pediatr. 1997;4:886-92.

23. Norton A, Glick PC. One parent families: a social and economics profile. Fam Relat. 1986;35:9-17.

24. Duncan GJ, Brooks-Gunn J, Klebanov PK. Economic deprivation and early childhood development. Child Dev. 1994;65:296-318.

25. Santrock JW, Warshak R, Lindberg CL. Meadows L. Children's and parents' observed social behaviour in stepfather families. Child Dev. $1982 ; 53: 472-80$

26. Clingepeel WG, Segal S. Stepparent-stepchild relationships and the psychological adjustment of children in stepmother and stepfather families. Child Dev. 1986;57:474-84.

27. Dornbusch SM, Carlsmith JM, Bushwall SJ, Ritter PL, Leiderman $\mathrm{H}$, Hastorf $\mathrm{AH}$, et al. Single parents, extended households, and the control of adolescents. Child Dev. 1985;56:326-41.

28. Healey JM Jr, Malley JE, Stewart AJ. Children and their fathers after parental separation. Am J Orthopsychiatry. 1990;604:531-43.

29. Kempton T, Armistead L, Wierson M, Forehand R. Presence of a sibling as a potential buffer following parental divorce: an examination of young adolescents. J Clin Child Psychol.1991;20:434-8.

30. Westman JC, Cline DW, Swift WJ, Kramer DA. Role of child psychiatry in divorce. Arch Gen Psychiatry. 1970;23:416-20.

Correspondence:

Alfredo Eymann

Crisólogo Larralde 3543 (code 1430),

Buenos Aires, BA - Argentina

Tel. : +54 (11) 3566.8001; +54 (11) 4541.7381

Fax: +54 (11) 4959.0200 int. 8484

E-mail: alfredo.eymann@hospitalitaliano.org.ar 